\title{
USE OF FORENSIC ACCOUNTING IN PREVENTION OF FRAUDS IN BURSARY DEPARTMENT, UNIVERSITY OF JOS, NIGERIA
}

\author{
${ }^{1}$ Nankling Milaham (AAT), ${ }^{2}$ Muplang Milaham
}

${ }^{1}$ Department of Accounting, University of Jos, Nigeria

${ }^{2}$ Department of Economics, Nasarawa State University, Keffi

${ }^{2}$ milahammuplang@gmail.com ${ }^{2}$ (D) https://orcid.org/0000-0002-0561-519X

Corresponding author milahamnankling@gmail.com;

(i) https://orcid.org/0000-0002-4233-5015

Received: $28^{\text {th }}$ August, 2020 ; Revised: $13^{\text {th }}$ September, 2020; Accepted: $25^{\text {th }}$ September, 2020

\begin{abstract}
Introduction: Misuse of funds and fraudulent acts are the main causes of revenue leakage in both public and private sectors. They are detrimental to the success of every department or organization. Fraud is a worrisome issue and a thing of concern to management of University of Jos.

Purpose: This study focused on the use of forensic accounting in prevention of frauds in Bursary Department, University of Jos, Nigeria..

Methodology: Cross sectional research was used as a design for the study. Data was generated from both primary and secondary sources through the use of Forensic Accounting Skills Checklist for Fraud Detection (FASCFD). All the staff in the Bursary department were involved in the study. Simple percentage was used to analyze the research questions. To ensure that the items in the questionnaire are relevant and appropriate, the instrument was subjected to thorough scrutiny by an expert in forensic accounting in the Department of Accounting, University of Jos. The constructive criticisms, suggestions and recommendations were strictly adhered to in producing the final draft of the instrument.

Results: The outcomes of the study revealed that forensic accounting have significant impact on the staff's ability to check fraudulent activities in the Bursary department of the university. It was also found that acquisition and use of forensic accounting skills can help to deter staff from committing fraudulent acts that concern funds in their possession.

Recommendations: The researchers recommended that the management of the University should ensure that there is regular forensic auditing of financial records kept by the Bursary Department. The staff of the Bursary Department in the University should be continuously trained in forensic accounting processes and procedures to enable them meet up with the global best practices in financial reports.
\end{abstract}

Keywords: Accounting skills, Fraud, Forensic accounting, Internal control, Funds, Revenue Leakage

Crossref Miliham, N., \& Miliham, M. (2020). Use of forensic accounting in prevention Cited-by of frauds in bursary department, University of Jos, Nigeria. Journal of Educational Research in Developing Areas, 1 (1), 80-87. https://doi.org/10.47434/JEREDA.1.1.2020.80.

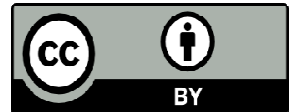

Copyright (c) 2020 The author(s) of this article retain(s) the copyright. 


\section{PUBLIC INTEREST STATEMENT}

The results of this research helped staff in the Bursary Department of Universities with strategies for use to reduce financial leakages in their institutions to the barest minimum. Acquisition of forensic accounting skills helped them record inflow and outflow of funds accruing to the University correctly and professionally. Finally, the result of this study is beneficial to the staff as it helped them apply forensic accounting skills to check financial entries with a view to eradicate fraud and enhance prompt payment of staff's salaries and other emoluments which normally arise as a result of misappropriation of funds.

\section{INTRODUCTION}

Forensic accounting has become a global tool for use in all businesses, corporate organizations, and the public sector to combat financial fraud. In Nigeria, companies have realized the need for the service of a forensic accountant to prevent and detect fraudulent cases in educational and financial institutions. Due to frequent corporate frauds and collapses of most companies, human and financial institutions, the quest for forensic accounting skills cannot be overemphasized. Frauds are committed daily as many people do it with little or no fear of being caught. Forensic accounting as a special accounting and auditing practice is employed to analyze information that can be used when there is an allegation of fraud.

Forensic accounting according to Popoola, Che-Ahmed, Samsudin, Salleh, and Babatunde (2016) is a process whereby accounting skills and knowledge are employed to investigate fraudulent activities or misappropriation of funds in an institution or organization. Fraud is any diverse means human beings use to get themselves enriched at the detriment of the organization. Fraud could include; surprises, tricks, cunning or dissembling, and any unfair way by which another person or organization is cheated. Onodi, Okafor, and Onyali (2015) stated that forensic skills are required to uncover financial crimes and establish a strong internal control system in any ministry, department or agencies. Dada, Owolabi and Okwu (2013) outlined some of the fraudulent crimes that are committed by criminals in organizations to include: illegal means of acquiring and possessing assets to the disadvantages of other persons.

Fraudulent activities occur in departments and agencies due to operational inefficiencies, financial misappropriation, and inability to follow due process among a host of other reasons
(Rezaee, Daniel, Micheal, \& Alexis, 2016). In most cases, departments and agencies do not often employ the services of a forensic accountant who brings forensic accounting skills to checkmate the activities of the workers. Abhyankar (2014) stated that revenue leakage is the gap between the actual revenue and the estimated revenue, as per records. It is one of the most pressing problems of organizations, but surprisingly most organizations are taking too little or no precaution at all to stop the porosity of their hard earned revenue. Apart from regular revenue audits, system integration reviews, and the eradication of manual processes on firms and institutions involved, financial transaction should be blocked through the use of forensic accounting processes.

In Nigeria, many educational institutions ought to be fraud-free; however, these institutions are areas where most frauds are committed. For example, in the Bursary Department of the University of Jos where different financial activities are carried out such as; students' tuition, academic, and non-staff emoluments or remuneration, lots of students and staff often complain of school fees not being paid into the appropriate University's account and name of staff omitted or considered as being paid their honorarium respectively. Some of these fraudulent activities are done deliberately, while others occur unknowingly. Oseni (2017) stated that the sophisticated nature of frauds performed in organizations and institutions have rendered auditing and investigation very difficult.

This study is anchored on Fraud Triangle Theory (FTT) developed in 1950 by Donald Cressey. This theory states that people have reasons for committing crime. These reasons are based these three elements namely; pressure, opportunity and rationalization which must be present before an offense can take place. These elements are diagrammatically shown below: 


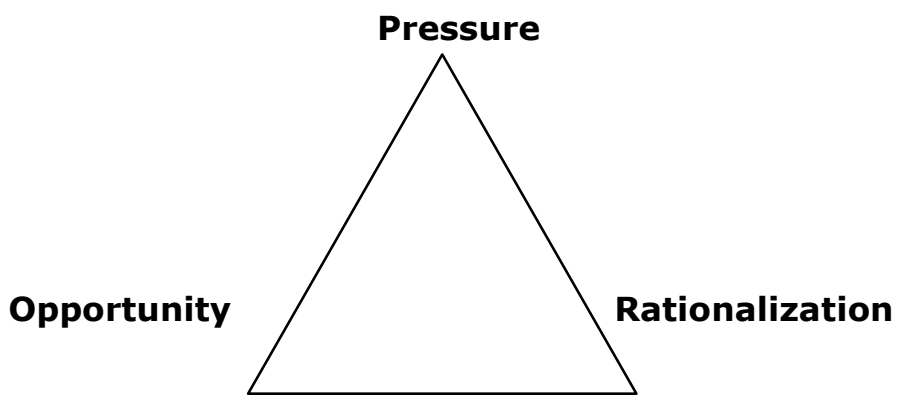

Fig.1 Fraud Triangle Theory (FTT)

The top element in the Cressey's theory represents pressure to commit the fraud. Pressure according to Mbasiti, Jugu, and Okwoli (2017) is always perceived and motivated in the mind of the perpetrator, while opportunity and rationalization are perceived as chances to commit the act. Abdullahi and Mansor (2015) stated that opportunity opens the door to fraud, while pressure and rationalization lead a person towards the door. Crime is always committed at the pressure level as a result of financial or material greed. Greed pressurizes the individual into committing fraud. Opportunity on the other hand is created by ineffective or porous control or governance that allows staff's activities to go unchecked. This, according to Milaham (2020) is referred to as internal control weakness. Rationalization occurs when an individual justifies his or her fraudulent act with his/her personal code of ethics. It is based on the frequent complaint of decline in Internally Generated Revenue (IGR) by the University that the researchers proposed the use of forensic accounting by the Bursary Department to checkmate payments and entries.

\section{STATEMENT OF THE PROBLEM}

Fraudulent activities have serious consequences on financial management and revenue generation of departments and agencies. These frauds constitute parts of the major setbacks that often bedevilled institutions in Nigeria. Fraud shrinks funds meant for the day to day running of departments and agencies; it retards the developmental efforts of the institutions. There are fraudulent activities such as embezzlement, larceny, and so on that is impediments to the development the Bursary department. Other causes of fraud according to Jugu and Ajita (2016) include: financial pressure, economic hard times, decrease earnings, expensive habits, illicit sexual relationships and living beyond ones means. In most institutions or organizations, attitudes, lack of salary payment, belief of being over worked and belief that everyone is doing it, often influence individuals to commit fraud.

In the Bursary Department of the University of Jos, there are non-observance of laid-down rules and regulations for the transaction of funds by staff in their assigned offices. Some procedures and policies established by University management and governing councils are not dully followed by some of its workers. In most cases, structural systems such as forensic accounting processes not employed to check the excesses of such staff. Some organizations and institutions do not have an efficient, strong, and reliable internal control system to protect their assets from possible losses. Oyedeji (2015) stated that forensic accounting is not always employed to check the activities of staff working in Bursary, accounts, and student affairs departments. It is based on these that this research was carried out to determine how forensic accounting could be used to prevent fraudulent activities in the Bursary unit of the University of Jos.

\section{PURPOSE OF THE STUDY}

The main purpose of this study is to examine the use of forensic accounting prevent fraudulent activities in the University of Jos. Specifically, the objectives are to:

1. Identify the causes of fraudulent activities in the University of Jos, Bursary Department

2. Determine how forensic accounting can be used to prevent fraudulent 
activities in the Bursary Department of University of Jos

3. Determine the impacts of forensic accounting on fraudulent activities in the Bursary Department of University of Jos?

\section{RESEARCH QUESTIONS}

The following research questions are set to guide the study:

1. What are the causes of financial fraud in the Bursary Department of University of Jos

2. To what extent can forensic accounting prevent fraudulent activities of staff in Bursary Department of University of Jos?

3. What is the impact of forensic accounting on staff's ability to detect frauds in Bursary department of University of Jos?

\section{METHODOLOGY \\ Research Design}

Cross-sectional design was employed for the study. A cross-sectional design was used because it helps the researchers to report the findings of a particular unit in the bursary. Forensic Accounting Skills Checklist for Fraud Detection (FASCFD) was used as an instrument for data collection. The data collected was analyzed using a simple percentage.

\section{Population and Sample}

The population used for this study consisted of all staff of the Bursary department, University of Jos. The staff in this department were chosen because the researchers believe that by the virtue of their placement in that department, they must know the inflow and outflow of funds (cash flow). They were also considered for the study because it is believed that they can check fraudulent activities as regards to financial misappropriation. Similarly, the sample for the study consisted of all the 15 staff in the Bursary department.

\section{Instrument for Data Collection}

The instrument used for data collection was the Forensic Accounting Skills Checklist for Fraud Detection (FASCFD) developed by the researchers. The checklist consisted of ten statements which the respondents were asked to tick either YES or NO as it appealed to them.

To ensure the appropriateness and comprehensiveness of the instrument, it was subjected to scrutiny by experts in the Accounting Department. The experts examined the content and extent to which the FASCFD measured staff's ability to detect fraudulent activities in the bursary department. They also measured the relevance of the instrument in detecting fraudulent activities in the Bursary department. To ensure the reliability of the instrument, it was first administered to on staff of the students' affairs division and adjustment made before it was used for this study.

\section{Procedure for Data Analysis}

The researchers took permission from the Bursar to allow them administered the questionnaire to the staff. Statement of confidentiality was attached to the questionnaire. The staff were asked not to use their real names.

\section{Method of data analysis}

The researchers used tables and simple percentages to analyze the data collected. The choice of simple percentage for this research is to make the results easier to understand.

\section{RESULTS AND DISCUSSIONS}

Research Question 1: What are the causes of financial fraud in the Bursary Department of University of Jos?

Table 1: Causes of Financial Fraud

\begin{tabular}{|c|c|c|c|c|c|c|}
\hline$\overline{\mathbf{S} / \mathbf{N}}$ & Causes & $\begin{array}{r}\text { Yes } \\
\text { Respon }\end{array}$ & $\%$ & No & $\%$ & Total \\
\hline$\overline{1}$ & Greediness & 11 & 73.3 & 04 & 26.7 & 15 \\
\hline 2 & Lack of Transparency & 02 & 13.3 & 13 & 86.7 & 15 \\
\hline 3 & Pressure & 14 & 93.3 & 01 & 6.7 & 15 \\
\hline 4 & Opportunity & 13 & 86.7 & 02 & 13.3 & 15 \\
\hline 5 & Poor internal control system & 04 & 26.7 & 11 & 73.3 & 15 \\
\hline 6 & Administrative ineffectiveness & 10 & 66.7 & 05 & 33.3 & 15 \\
\hline
\end{tabular}

Volume 1, Number 1 (Inaugural Edition) 
The table above shows the percentage scores of respondents according to the causes of financial fraud the Bursary Department of the University. Eleven (11) respondents representing $73.3 \%$ agreed that greediness is a cause of financial fraud, four (4) respondents representing $26.7 \%$ responded in the negative. Two (2) of them representing $13.3 \%$ agreed that lack of transparency is a cause of financial fraud in the school, while also, fourteen (14) respondents $93.3 \%$ agreed that pressure is a cause of financial fraud in institutions and only one (1) respondent representing $6.7 \%$ responded in the negative. This agrees with Mbasiti et al, (2017) who noted that pressure is perceived in the mind of the perpetrator and is motivated from within to commit fraud.

On whether opportunity is a cause of fraud, thirteen (13) of the respondents representing $86.7 \%$ agreed that opportunity is a major cause of financial fraud in financial institutions, while only two (2) respondents representing $13.3 \%$ did not agree. This again implies that when staff get opportunity to perpetrate fraudulent acts, they do immediately. On the issue of poor internal control system, Four (4) respondents representing $26.7 \%$ agreed that the internal control system in the bursary department is porous. This shows that the department is properly controlled hence $73.3 \%$ of the staff responded in the negative. In addition, on whether administrative ineffectiveness can cause fraudulent activities in organisation ten (10) respondents representing $66.7 \%$ agreed that administrative ineffectiveness is a major cause of financial fraud in the Bursary unit of University of Jos, while five (5) respondents representing $33.3 \%$ did not agree. This is in line with Popoola, et al (2016) opinion who stated that inability of accountants to acquire forensic skills for use to investigate fraudulent activities or misappropriation of funds in their institutions is a major concern to institutions and departments.

Research Question 2: To what extent can use of forensic accounting prevent fraudulent activities in Bursary Department of University of Jos?

Table 2:

Level which Forensic Accounting was able to Prevent Fraud in University of Jos

\begin{tabular}{llll}
\hline S/N & Level & Frequency & Percentage \\
\hline $\mathbf{1}$ & Low & 01 & 6.7 \\
$\mathbf{2}$ & Medium & 04 & 26.7 \\
$\mathbf{3}$ & High & 10 & 66.6 \\
& Total & $\mathbf{1 5}$ & $\mathbf{1 0 0}$
\end{tabular}

The table above shows the percentage scores of respondents based on the level at which forensic accounting skills can prevent fraudulent activities in the Bursary Department of the University. Sixty-six point six percent $(66.6 \%)$ of the respondents were of the opinion that acquisition of forensic skills is a major way to prevent fraudulent activities by staff who handle funds. This in line with Popoola et al (2016) who stated that the use of accounting skills and knowledge to investigate fraudulent activities or misappropriation of funds in financial institutions cannot be over emphasized. This according to them remains the best way to check fraudulent activities. About $26.7 \%$ and $6.6 \%$ of the respondents did not see forensic accounting as a highly reliable means of checking revenue leakages. The researchers' personal experiences in their various Universities show that forensic accounting is not always use by Bursary Departments to check financial crimes in the institutions. Oyedeji (2015) also agreed that forensic accounting is not always employed to check the activities of staff working in Bursary, accounts, and student affairs departments. Based on these results, the researchers concluded that forensic auditing should be carried out periodically in the Bursary Department of the University to prevent fraudulent activities by the staff. 
Journal of Educational Research in Developing Areas (JEREDA)

Vol. 1. Issue 1, Pp. 80-87, Inaugural Edition, 2020

https://www.jeredajournal.com

E-mail: info@jeredajournal.com

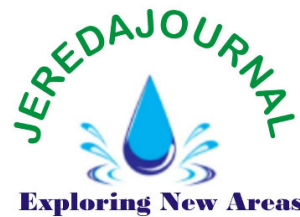

Research Question 3: What is the impact detect frauds in Bursary Department of of forensic accounting on staff's ability to University of Jos?

Table 3: Impact of Forensic Accounting on Staff's Ability to Detect frauds

\begin{tabular}{llll}
\hline S/N & Impact & Frequency & Percent \\
\hline $\mathbf{1}$ & Significantly Low & 01 & 6.7 \\
$\mathbf{2}$ & Significant & 05 & 33.3 \\
$\mathbf{3}$ & Significantly High & 09 & 60.0 \\
& Total & $\mathbf{1 5}$ & $\mathbf{1 0 0 . 0}$ \\
\hline
\end{tabular}

The table above shows the percentage scores of respondents based on the impact of forensic accounting skills in coping fraudulent activities in Bursary Department of University of Jos. From the analysis, nine (9) of the respondents representing $60.0 \%$ stated that acquisition of forensic accounting skills by the staff have high significant impact on their ability to detect fraudulent activities involving funds in the department. This result agrees with Onodi, Okafor, and Onyali (2015) who stated that acquisition of forensic skills are required to uncover financial crimes such as misappropriation of funds that poses threat to institutions and departments. Only $33.3 \%$ of the respondent responded that it has significant impact on the staff's ability to check misappropriation of funds, while an insignificant number of them, $6.7 \%$ stated that acquisition of forensic accounting skills has no impact on the staff's ability to check financial crime in the Bursary department. This means that these staff have no knowledge of forensic accounting. A further prop to confirm their level of professionalism in forensic accounting showed that, many staff of the department are not members of any accountancy body such as the Association of Accountancy Bodies in West Africa (AABWA), Institute of Chartered Accountants of Nigeria (ICAN) nor Association of National Accountants of Nigeria (ANAN). Based on the aforementioned, the staff do not fully qualify to perform forensic audits of the department, Milaham (2020) stated that an accountant must have undergone these stages and certified as a professional accountant to be allowed to carry out forensic auditing in institutions or department that handle funds. Base on this result, the researchers concluded that acquisition of forensic accounting skills have great impact on prevention of fraudulent activities of staff working in the Bursary Department of University.

\section{SUMMARY OF FINDINGS}

Based on the results of the analysis, the following findings were arrived at:

a. Greediness, pressure, opportunity, poor internal control system, and administrative ineffectiveness among others are major causes of financial fraud in the Bursary Department of University of Jos

b. Poor internal control systems and lack of administrative transparency are the major causes of financial fraud in the Bursary unit of University of Jos.

c. Forensic accounting have very significant impact in preventing fraudulent activities committed by staff in the Bursary unit of University of Jos.

\section{CONCLUSION}

The use of forensic accounting skills in managing funds in departments that handle funds cannot be over emphasized. This is because the acquisition and use of these skills helps to uncover fraudulent practices committed by staff in such departments. The increasing occurrence of fraud in the Bursary department requires the services of forensic accountants to unearth the fraudulent activities within and outside the system. Forensic accountants are therefore major stakeholders in the control of financial leakages in all departments that handle funds.

\section{RECOMMENDATIONS}

Based on the findings of this study, the following recommendations are made: 
1. Good internal control systems and transparency among member staff should be adopted to reduce or stop financial fraud in the Bursary Department.

2. The existence of a functional forensic accounting system for the Bursary Department should be utilized to deter staff from committing fraudulent activities that can cause collapse of the department.

3. Staff of internal audit should be continuously trained on forensic accounting processes and procedures to periodically audit the account of the Bursary Department.

\section{Conflict of Interest}

The authors declare no conflict of interest.

\section{Acknowledgment}

The researchers acknowledged the staff of the Bursary Department of University of Jos for their cooperation during the collection of data for the study. Our sincere appreciation also goes to Dr. Yohanna Jugu for validating the instrument used for this research work.

\section{Notes on Authors}

Nankling Milaham is a student in the department of accounting, University of Jos. She is also an associate member of the Association of Accountancy Bodies in West Africa.

Muplang Milaham is a student in the Department of Economics, Nasarawa State University, Keffi.

\section{Authorship and Level of Contribution}

Nankling Milaham is the principal author. She played active role in the development of research instruments and collection of data used for the study.

Muplang Milaham took part in the computation and analysis of data used for the study.

\section{Disclaimer Statement}

The work is part of the degree project submitted to the University for award of a degree.

\section{References}

Abdullahi, R., \& Mansor, N. (2015). Fraud triangle theory and fraud diamond theory: Understanding the

Volume 1, Number 1 (Inaugural Edition)

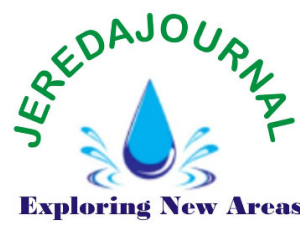

convergent and divergent for future research. International Journal of Academic Research in Accounting, Finance and Management Sciences, $5(4), 2.14$.

Abhyankar, P. (2014). Are the complexities of revenue leakages slowing your business down?

http://blog.tavisca.com/travel-

technology-solutions/complexitiesrevenue-leakages-slowing-travelbusiness-down/.

Cressey, D. R. (1950). The criminal violation of financial trust. American Sociological Review, 15 (6), 1-15

Dada, S. O., Owolabi, S. A., \& Okwu, A.T. (2013). Forensic accounting: A panacea to alleviation of fraudulent practices in Nigeria. Unique Journal of Business Management Economics Research, 1(15), 96-99.

Mbasiti, T. H., Jugu, Y. G., \& Okwoli, A. A (2017). Forensic accounting skills and techniques: A Panacea for preventing revenue leakages in Nigerian Universities. International Journal of Management Science Research, 2 (1), 2-3.

Milaham, N. S. (2019). Effects of forensic accounting skills on prevention of revenue leakages in University of Jos: A case study of Bursary Department, Unijos. A Bsc undergraduate project work. University of Jos, Nigeria.

Onodi, B. E., Okafor, T. G., \& Onyali, C. I. (2015). The impact of forensic investigative methods on corporate fraud deterrence in banks in Nigeria. European Journal of Accounting, Auditing and Finance 3(4), 69-85.

Oseni, A. (2017). Forensic accounting and financial fraud in Nigeria: Problems and prospects. Journal of Accounting and Financial Management, 3 (1), 23-33.

Oyedeji, R. O. (2015) Impacts of computerized internal control systems on fraud detection: A study of three selected Nigerian Universities: An M.sc research work, University of Lagos, Nigeria.

Popoola, O., Che-Ahmed, A., Samsudin, R., Salleh, K., \& Babatunde, A. (2016). Accountants' capability requirements for fraud prevention and detection in Nigeria. 
Journal of Educational Research in Developing Areas (JEREDA)

Vol. 1. Issue 1, Pp. 80-87, Inaugural Edition, 2020

https://www.jeredajournal.com

E-mail: info@jeredajournal.com

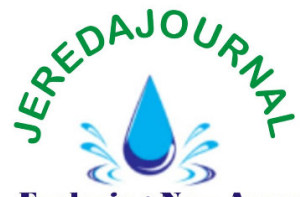

International Journal of Economics and Financial Issues, 6 (4), 1-10.

Rezaee, Z, Daniel, L., Micheal, H., \& Alexis, S. (2016). Forensic accounting education and practice: Insights from China: Journal of Forensic and Investigation Accounting, 8 (1), 106-119.

Wolfe, D. T., \& Hermanson, D. R. (2004). The Fraud Diamond: Considering the Four Elements of Fraud. $74(12), 38-42$. 